\title{
How do inorganic nitrogen processing pathways change quantitatively at daily, seasonal and multi-annual scales in a large agricultural stream?
}

\author{
Jingshui Huang ${ }^{1,2}$, Dietrich Borchardt ${ }^{2}$, Michael Rode ${ }^{2}$
}

$5{ }^{1}$ Chair of Hydrology and River Basin Management, Technical University of Munich, Arcisstrasse 21, 80333 Munich, Germany ${ }^{2}$ Department of Aquatic Ecosystem Analysis, Helmholtz Centre for Environmental Research - UFZ, Brueckstrasse 3a, 39114 Magdeburg, Germany

Correspondence to: Jingshui Huang (jingshui.huang@tum.de)

Abstract. Instream nitrogen $(\mathrm{N})$ processing consists of complex interacting and highly time-varying pathways. To understand

10 the role of a large agricultural stream river reaches in processing $\mathrm{N}$ thoroughly, it is urgently needed to continuously quantify high temporal resolution $\mathrm{N}$ processing pathways, reflecting seasonal shifts and multi-annual overarching effects. To this end, the hydrodynamic and river water quality model WASP 7.5.2 was applied in the 27.4-km reach of the 6th order agricultural stream Lower Bode (central Germany) for 5 years (2014-2018). Paired high-frequency data (15-min interval) of discharge (Q), nitrate $\left(\mathrm{NO}_{3}{ }^{-}\right)$, dissolved oxygen (DO), and Chlorophyll-a at upstream and downstream stations were used as model boundaries and for model constraints. The WASP model simulated 15-minute intervals of $\mathrm{Q}, \mathrm{NO}_{3}{ }^{-}$and DO with Nash-Sutcliffe-Efficiency values higher than 0.9 for calibration and validation, enabling the calculation of gross and net dissolved inorganic $\mathrm{N}$ (DIN) uptake and pathway rates on a daily, seasonal and multi-annual scale. Results showed daily DIN net uptake rate ranged from $-17.4 \mathrm{mg} \mathrm{N} \mathrm{m}^{-2} \mathrm{~d}^{-1}$ to $553.9 \mathrm{mg} \mathrm{N} \mathrm{m}^{-2} \mathrm{~d}^{-1}$. The highest daily net uptake could reach almost $30 \%$ of total input loading, which occurred at extreme low flow in summer 2018. The growing season (spring and summer) accounted for $91 \%$ of the average net annual DIN uptake in the measured period. In spring, both the DIN gross and net uptake were dominated by the phytoplankton uptake pathway. In summer, benthic algae assimilation dominated the gross DIN uptake. Conversely, the reach became a DIN net source with negative daily net uptake values in autumn and winter, mainly because the release from benthic algae surpassed uptake processes. Over the five years, average DIN gross and net uptake rates were 124.1 and $56.8 \mathrm{mg} \mathrm{N}^{-2}$ $\mathrm{d}^{-1}$, which accounted for only $2.7 \%$ and $1.2 \%$ of the total loadings the study reach in the Lower Bode, respectively. 5 -year average gross DIN uptake decreased from assimilation by benthic algae through assimilation by phytoplankton to denitrification. Our study highlights the value of combining river water quality modelling with high-frequency data in obtaining reliable instream DIN-budget, which facilitates our ability to manage $\mathrm{N}$ in aquatic systems. This study provides a methodology that can be applied to any large stream to quantify $\mathrm{N}$ processing pathway dynamics and complete our understanding of $\mathrm{N}$ cycling. 


\section{Introduction}

The instream processing of dissolved inorganic nitrogen (DIN) consists of complex and multiple simultaneous pathways (Hensley and Cohen, 2020). The dominant pathway processes include nitrification, denitrification, autotrophic uptake and release, heterotrophic uptake and release, and mineralization (Burgin and Hamilton, 2007; Tank et al., 2018). Disentangling these interacting processes at the reach scale is challenging because they coincide in streams and share the same DIN constituents for their substrates and products. The classic method for reach-scale DIN pathway quantification is the addition of DIN isotope tracers (Mulholland et al., 2008). Using this methodology, Mulholland et al. (2008) quantified the shares of denitrification and assimilation on total nitrate $\left(\mathrm{NO}_{3}{ }^{-}\right)$in-stream uptake in the Lotic Intersite Nitrogen eXperiment (LINX) Project in a wide range of biomes. This method's main limitation is that it is difficult to apply in high-order streams and can only provide snapshots of the highly dynamic processes. For high-order streams, Heffernan and Cohen (2010) developed a method of calculating mass balance using high-frequency measurements to allow partitioning $\mathrm{NO}_{3}{ }^{-}$uptake rates into assimilatory and dissimilatory pathways in a spring-fed river. To achieve a continuous estimation of assimilatory uptake, Rode et al. (2016) correlated daily assimilatory $\mathrm{NO}_{3}{ }^{-}$uptake with gross primary production (GPP) using high-frequency oxygen and $\mathrm{NO}_{3}{ }^{-}$data. However, both methods rely on a robust diel pattern of $\mathrm{NO}_{3}{ }^{-}$concentration fluctuations, which is possibly only obtained where external inputs are well constrained and difficult to obtain in large agricultural streams (Hensley and Cohen, 2020). Due to the lack of effective methods, quantification of DIN processing pathways in large agricultural streams remains poorly explored.

Besides, each pathway process is highly time-varying (Hensley and Cohen, 2020). As a vital DIN processing pathway, autotrophic assimilatory uptake is affected by light availability, temperature, autotrophic biota and presents significant seasonal changes (Tank et al., 2017). Furthermore, denitrification, nitrification, and mineralization also exhibit seasonal changes due to

50 the influences of temperature, substrate concentrations, and hydrological conditions (Burgin and Hamilton, 2007; Verstraete and Focht, 1977). Phytoplankton and benthic algae might co-exist in high-order agricultural streams and their metabolism both determine autotrophic assimilatory uptake (Durand et al., 2011). The temporal changes in their relative importance for reachscale assimilatory DIN uptake is still not well known (Jäger and Borchardt, 2018; Riis et al., 2012). Many studies have reported that DIN can be largely assimilated and fixed in benthic algae's biomass during the growing season (Mulholland et al., 2008).

55 However, few studies have paid attention to the fate of assimilated nitrogen (N) during the non-growing season (Riis et al., 2012; Tank et al., 2018). It is unclear whether the DIN release can exceed gross uptake in the non-growing season and if temporally decoupled DIN uptake and release can cause a seasonal shift of DIN release from stream biomass. Von Schiller et al. (2015) quantified $\mathrm{N}$ release by comparing gross and net uptake and found that the streams remained at a biogeochemical steady state on a time scale of hours. However, the knowledge about the DIN release on longer time scales, such as of seasons,

60 still lacks due to measurement constraints (von Schiller et al., 2015). In addition, considering the highly dynamic nature of the processes, it is uncertain to interpolate and aggregate instream DIN uptake rates from snapshot experiment results in the growing season to estimate how effective a river reach is in processing DIN at annual or multi-annual scales. In order to gain 
overarching insights into the DIN fate in streams, it is therefore needed to quantify the DIN pathways not only on a daily or weekly basis within the growing season but also continuously throughout the hydro-climatic year and beyond.

Instream water quality models offer synthesis tools to study spatio-temporal variation and DIN turnover processes in streams/rivers (Wagenschein and Rode, 2008; Raimonet et al., 2015; Huang et al., 2019). However, the infrequent temporal resolution of monitoring data for model input and testing commonly restricts the reliability of modelling instream DIN processing (Khorashadi Zadeh et al., 2019). A limited temporal resolution of data can result in the equifinality of model parameter sets and considerable model uncertainties due to the insufficient ability to validate single internal reaction processes (Khorashadi Zadeh et al., 2019). Emerging high-frequency monitoring techniques can provide higher temporal resolution of boundary conditions and support robust calibration and validation of "data-hungry" mechanistic models (Hamilton et al., 2015; Kong et al., 2019). Thus, combining emerging high-frequency monitoring techniques and river water quality modelling may allow continuous quantification of instream DIN processing pathways and increase their reliability (Rode et al. 2016b).

Therefore, in this study DIN processing pathways were examined using a five-year paired high-frequency water quality dataset from a 27.4-km reach of the $6^{\text {th }}$ order agricultural Bode stream in Central Germany and a complementary setup of the river water quality model WASP7.5.2. With this methodological approach, the instream rates of gross and net DIN uptake, denitrification, autotrophic uptake and release by phytoplankton and benthic algae were quantified at daily, seasonal, and yearly scales. The objectives of this study are to answer three questions: (1) how temporally variable are the DIN uptake and pathways on a daily scale? (2) Are there seasonal shifts in the role of river reach as $\mathrm{N}$ source and sink? If so, what is the pathway dominating this shift? (3) Based on the continuous multi-year DIN budget, how effective is the river reach in processing DIN and what are its dominant pathways? Finally, our findings highlight the utility and value of high-frequency data to support river water quality modelling in allowing continuous quantification of instream $\mathrm{N}$ uptake pathways and thus improving our understandings of the biogeochemical functioning of the large streams on $\mathrm{N}$ cycling and fate.

\section{Material and Methods}

\section{$85 \quad 2.1$ Study site}

The Bode River is a $169-\mathrm{km}$ long $6^{\text {th }}$ order stream in Saxony-Anhalt, originating in the Harz Mountains and discharging into the Saale. It drains a watershed area of $3270 \mathrm{~km}^{2}$. The Bode Catchment is one of the most intensively monitored areas within the Terrestrial Environmental Observatories (TERENO) network (http://www.tereno.net) operated by the Helmholtz Centre for Environmental Research (UFZ). The land use within the basin varies along a longitudinal gradient, with the headwaters dominated by forests while the lower reaches dominated by intensive agriculture and partly by urban land. Due to intensive agricultural activities, the Bode River is characterized by high $\mathrm{NO}_{3}{ }^{-}$concentrations. 


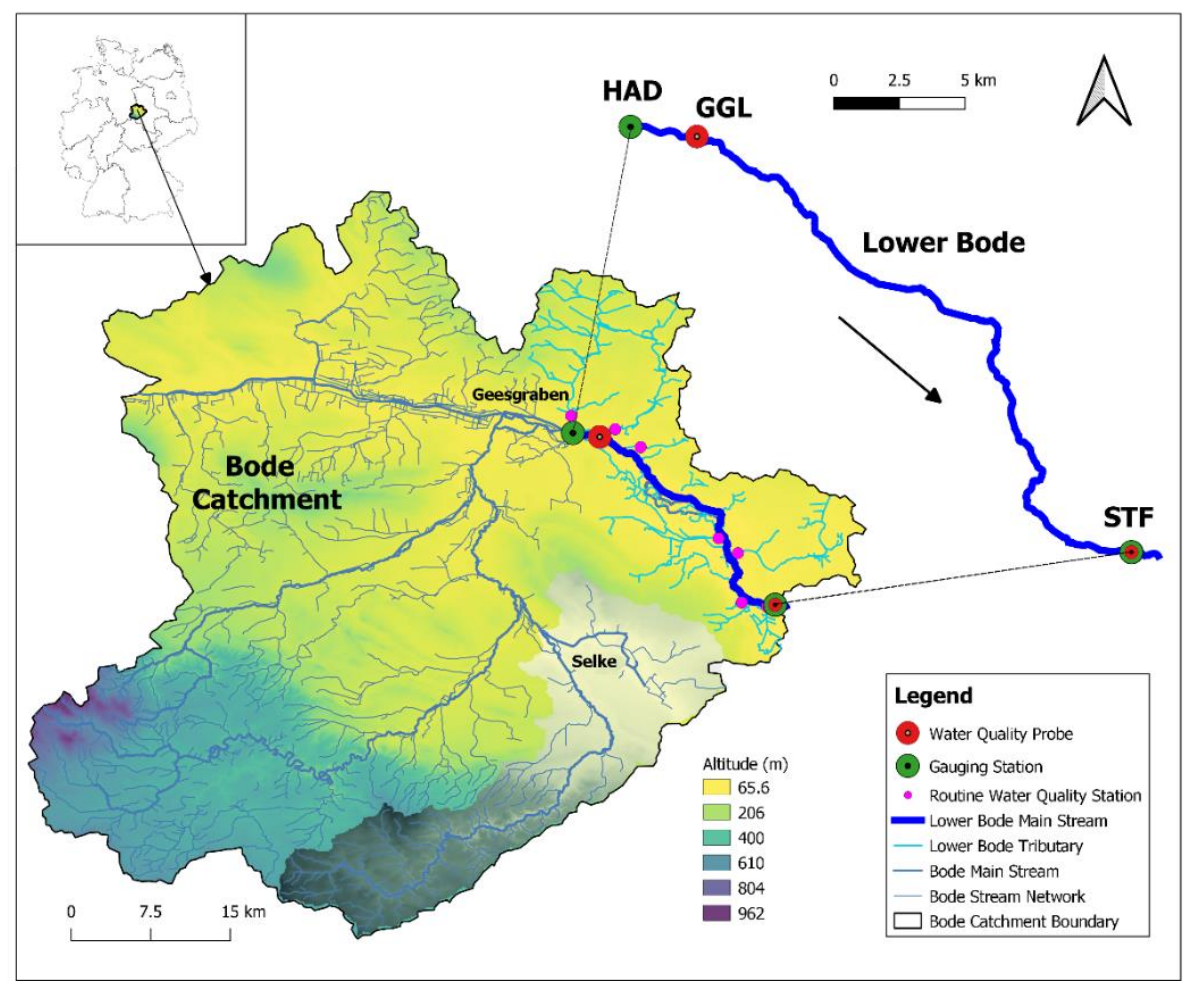

Figure 1. Bode catchment, stream networks, DEM, study reach of Lower Bode, and site description of Lower Bode. The red circles donate the high-frequency water quality sensors. The green circles denote the gauge stations. The pink circles depict the routine water quality monitoring stations of the tributaries. HAD, GGL and STF stand for the monitoring station names of Hadmersleben, Groß Germersleben, and Staßfurt, respectively. The grey shaded area represents the Selke sub-catchment.

We studied a 27.4-km reach of the Lower Bode River between Groß Germersleben (GGL) and Staßfurt (STF), with two discharge gauging stations at both ends (Fig. 1). The land use is mainly agricultural and to a minor degree urban. The mean depth of the reach is $60 \mathrm{~cm}$. The mean stream width is $20 \mathrm{~m}$. The stream bed substrate is sand and small gravel. The reach has a mean river slope of $0.4 \mathrm{~m} / \mathrm{km}$ with rectangular or trapezoidal cross-sections. Three weirs are installed in the reach. The original meandering reach has been mostly straightened or re-routed artificially over the past century (LHW, 2012). Lined deciduous trees on the banks only partly shade the reach. The insufficient shading and open canopy allow high irradiance at the water surface and the subsequent development of phytoplankton and benthic algae.

\subsection{Hydrological and water quality data}

Discharge (Q) data at 15-min intervals were obtained at the gauging station Hadmersleben (HAD), which is located $2.7 \mathrm{~km}$ upstream of the water quality station GGL, and at the downstream station STF from the hydrological state authority of SaxonyAnhalt (LHW). We assume that discharge at station HAD is also valid for station GGL because no lateral flow contributes to the reach between the two stations. 
Daily discharges of the 8 small tributary streams within the study reach were calculated based on monthly discharge measurements from LHW and by the specific discharge method. The reference gauging station measures daily $\mathrm{Q}$ at the outlet of a similar stream, Geesgraben, about $0.5 \mathrm{~km}$ upstream of HAD (Fig. 1). Detailed descriptions about the Q estimations of the streams are provided in Supplementary Information (SI). The sum of the tributary flows accounted only for $5.88 \%$ of the upstream inflow over the whole study period. The percentage error of flow balance (eq. S2) between GGL and STF was $0.97 \%$. Hourly solar radiation was provided by the German Weather Service (DWD). All data were taken for 5 years (01.01.2014 -

$115 \quad 31.12 .2018)$.

Paired high-frequency water quality sensors were installed at GGL and STF. Water temperature (WT), dissolved oxygen (DO), $\mathrm{pH}$, and chlorophyll-a (Chl-a) were measured with a YSI 610 multiparameter probe at 15-min intervals. $\mathrm{NO}_{3}{ }^{-}$ measurements were also conducted at 15-min intervals using a TRIOS ProPS-UV sensor with an optical path length of $10 \mathrm{~mm}$. Self-cleaning of the sensor was done with air pressure before every measurement. Maintenance of all sensors, including manual cleaning and calibration, was done monthly. All high-frequency water quality measurements were matched with $Q$ by date and time except Chl-a. Chl-a was only measured from spring to autumn, typically from April until November. All high-frequency data were screened to eliminate outliers based on Grubb's test using a moving window method for post-processing. Additionally, the sensor data curves were adjusted to the laboratory measurements from the grab samples by linear regression.

Meanwhile, grab samples were collected monthly for the study period at both stations, filtered and analyzed for $\mathrm{NO}_{3}{ }^{-}$, ammonium $\left(\mathrm{NH}_{4}{ }^{+}\right)$, total nitrogen (TN), orthophosphate $\left(\mathrm{PO}_{4}{ }^{3-}\right)$, total phosphorus (TP), and dissolved organic carbon (DOC) using standard methods (Rode et al., 2016a). Monthly 7-days biological oxygen demand $\left(\mathrm{BOD}_{7}\right)$ at $\mathrm{HAD}$ and STF were obtained from Saxony-Anhalt Water Service data portal (GLD) (https://gld-sa.dhi-wasy.de/GLD-Portal/) for the study period. The molar carbon to nitrogen ratio $(\mathrm{C} / \mathrm{N})$ of the benthic algae in the Lower Bode is available in Kamjunke et al. (2015) with a value of 9.3. In this reach, the dominant taxonomic composition of benthic algae in biofilms was diatom, and the biomass in carbon was measured with grab sampling (Kamjunke et al., 2015).

Bi-monthly routine measurements of $\mathrm{NH}_{4}{ }^{+}, \mathrm{PO}_{4}{ }^{3-}, \mathrm{TP}, \mathrm{DO}$, and $\mathrm{BOD}_{7}$ for the 8 small tributary streams were obtained from GLD. As all the streams are in agricultural areas, we assumed $\mathrm{NO}_{3}{ }^{-}$concentrations are likely to be temporally variable and change with $\mathrm{Q}$. Thus, their concentration-discharge (C-Q) relationships were evaluated for all tributary streams with the longterm monitoring data from 1994 to 2016. All C-Q relationships for the tributaries with available data exhibit enrichment responses with positive slopes (Table S1). Daily $\mathrm{NO}_{3}{ }^{-}$concentration for each tributary was calculated by its $\mathrm{C}-\mathrm{Q}$ linear regression.

\subsection{Water quality modeling}

\subsubsection{Model description}

WASP 7.5.2 Advanced Eutrophication Module developed by the United States Environmental Protection Agency is a river 140 water quality model including nitrogen and phosphorus cycling, dissolved oxygen-organic matter interactions, and kinetics of 
both phytoplankton and benthic algae (Fig S1) (Wool et al., 2020). Its DIN processing equations characterize denitrification, assimilatory uptake and excretion by phytoplankton, assimilatory uptake and excretion by benthic algae, mineralization, and nitrification (Table 1). WASP 7.5.2 can simulate diurnal dynamics of water quality variables (Wool et al., 2002) and derive its outputs at the resolution of 15-min intervals, allowing full use of high-frequency data.

145 Table 1. Areal rates (in $\mathbf{~ m g ~} \mathbf{N ~ m}^{-2} \mathbf{d}^{-1}$ ) of DIN-related processes in the Advanced Eutrophication Module of WASP 7.5.2 ${ }^{1}$.

Process Notation Areal Rate

Denitrification

$$
U_{D} \quad k_{d n i t} \theta_{d n i t}^{T-20}\left(\frac{K_{N O 3}}{K_{N O 3}+C_{D O}}\right) C_{N O 3} \times z \times 1000
$$

Assimilatory uptake by phytoplankton

$$
U_{A, P} \quad G_{p} a_{N C} C_{P h y C} \times z \times 1000
$$

Excretion by Phytoplankton

Assimilatory uptake by benthic algae

Excretion by Benthic Algae

Mineralization
$R_{P}$

$$
D_{p} a_{N C}\left(1-f_{O N}\right) C_{P h y C} \times z \times 1000
$$

$$
U_{A, B}
$$$$
\rho_{m N}\left(\frac{C_{N H 4}+C_{N O 3}}{K_{S N b}+C_{N H 4}+C_{N O 3}}\right)\left(\frac{K_{q N}}{K_{q N}+q_{N}-q_{0 N}}\right) a_{b} \times 1000
$$

$R_{B}$

$$
k_{E b 20} \theta_{E b}^{T-20} q N a_{b}\left(1-f_{O N b}\right) \times 1000
$$$$
k_{\text {min }} E_{\text {min }}^{T-20}\left(\frac{C_{P h y C}}{K_{m p c}+C_{P h y C}}\right) C_{D O N} \times z \times 1000
$$

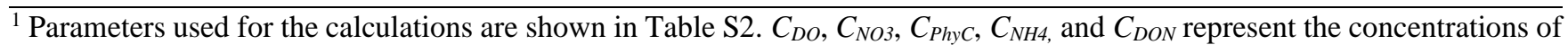
DO, $\mathrm{NO}_{3}{ }^{-}$, phytoplankton biomass carbon, $\mathrm{NH}_{4}{ }^{+}$, and DON, in mg/L. $q_{N}$ represents algal cell $\mathrm{N}$ in $\mathrm{mg}_{\mathrm{N}} / \mathrm{g}_{\mathrm{D}}$, and $a_{b}$ represents the bottom algal biomass in $\mathrm{g}_{\mathrm{D}} / \mathrm{m}^{2} . z$ donates the water depth $(\mathrm{m})$.

\subsubsection{Model setup}

150 The WASP model was set up for the 27.4-km study reach of the Lower Bode between GGL and STF for 5 years $(01.01 .2014$ - 31.12.2018). The entire reach was divided into 34 model segments, each with an average length of $806 \mathrm{~m}$. Average segment riverbed morphology was characterized by 413 cross-sectional profiles provided by LHW (LHW, 2012). The upper boundary condition was forced by the 15-min interval Q and monthly $\mathrm{BOD}_{7}$ at $\mathrm{HAD}, 15-\mathrm{min}$ interval for $\mathrm{NO}_{3}{ }^{-}$, $\mathrm{DO}$, and $\mathrm{Chl}-\mathrm{a}$, and monthly $\mathrm{NH}_{4}{ }^{+}, \mathrm{PO}_{4}{ }^{3-}$, and TP at GGL. The lateral boundary conditions were defined by the daily $\mathrm{Q}$ and $\mathrm{NO}_{3}{ }^{-}$concentrations,

155 and bi-monthly $\mathrm{NH}_{4}{ }^{+}, \mathrm{PO}_{4}{ }^{3-}, \mathrm{TP}, \mathrm{DO}$, and $\mathrm{BOD}_{7}$ concentrations of the 8 tributaries. Environmental conditions, including WT and solar radiation, were provided with the data mentioned in Section 2.2. Hydrological and water quality variables were simulated with variable-timesteps smaller than 1 min. 


\subsubsection{Sensitivity analysis, calibration \& validation}

Before calibration, sensitivity analysis (SA) was conducted to screen the parameters significantly influencing model outcomes.

31 parameters related to the DIN processes were defined with uniform distribution within the ranges previously reported (Table S2). The Elementary Effects (EE) method was used, and the analysis was performed using the SAFE toolbox (Pianosi et al., 2015). The objective functions were defined by the Root Mean Square Error (RMSE) coefficients of $\mathrm{NO}_{3}{ }^{-}, \mathrm{NH}_{4}{ }^{+}$, $\mathrm{DO}$, and Chl-a. 10 most sensitive parameters for $\mathrm{NO}_{3}{ }^{-}$and $\mathrm{NH}_{4}{ }^{+}$, and 2 additional parameters sensitive to DO and Chl-a were identified. After SA, the most identifiable parameters were automatically calibrated using the Gauss-Marquardt-Levenberg algorithm with OSTRICH v17.12.19. (Matott, 2017). The ranges of the selected parameters were defined the same as in the SA (Table S2). The objective function was defined as the sum of square error of the four variables $\left(\mathrm{NH}_{4}{ }^{+}, \mathrm{NO}_{3}{ }^{-}, \mathrm{DO}\right.$, and Chl-a) at STF for the calibration period of 01.01.2014 - 31.12.2015. We assigned the values to the other less sensitive parameters within the ranges frequently reported (Wool et al., 2002). After calibration, we evaluated the model performance in Q and water quality variables for the validation period of 01.01.2016 - 31.12.2018 using three criteria: Nash-Sutcliffe-Efficiency (NSE) coefficient, Percent Bias (PBias), and RMSE.

We calculated daily gross primary production (GPP) with the 15-min interval DO data using the single-station method (Rode et al., 2016a) and compared it with the sum of GPP of phytoplankton $\left(G P P_{p}\right)$ and benthic algae $\left(G P P_{b}\right)$ calculated with the WASP 7.5.2 model results:

$G P P_{p}=G_{p} \times C_{P h y C} \times R O C \times z$

$G P P_{b}=F_{G b} \div A D C \times R O C$

where $G_{p}$ is phytoplankton growth rate $\left(\mathrm{d}^{-1}\right) ; C_{P h y C}$ represent the concentration of phytoplankton biomass carbon $\left(\mathrm{mg} \mathrm{C} \mathrm{L}^{-1}\right)$; $R O C$ represents oxygen to carbon ratio $(\mathrm{gO} 2 / \mathrm{gC}) ; z$ donates the stream depth $(\mathrm{m}) ; F_{G b}$ is zero-order growth rate for benthic algae $\left(\mathrm{gD} \mathrm{m}^{-2} \mathrm{~d}^{-1}\right) ; A D C$ represents detritus to carbon ratio $\mathrm{gD} / \mathrm{gC}$. This procedure provides process validation besides variable validation, especially for phytoplankton and benthic algae growth parameters.

\section{$180 \quad 2.4$ Quantification of DIN uptake rates}

DIN input and output (in $\mathrm{kg} \mathrm{N} \mathrm{d}^{-1}$ ) were defined as the sum of the $\mathrm{NO}_{3}{ }^{-}$and $\mathrm{NH}_{4}{ }^{+}$loadings at GGL and tributaries, and the loading at STF, respectively. Areal rates of DIN-related processes (in $\mathrm{mg} \mathrm{N} \mathrm{m}^{-2} \mathrm{~d}^{-1}$ ) were calculated for each segment with the equations in Table 1 and were added up over the study river reach. The DIN inputs, output, and process rates were averaged daily, seasonally, and for the whole 5-year period. The seasons start with spring on Mar. $1^{\text {st }}$, summer on Jun. $1^{\text {st }}$, autumn on

185 Sept. $1^{\text {st, }}$ and winter on Dec. $1^{\text {st }}$.

The gross DIN uptake rate $\left(U_{G R O S S}\right.$, in $\left.\mathrm{mg} \mathrm{N} \mathrm{m}^{-2} \mathrm{~d}^{-1}\right)$ was calculated as the sum of denitrification rate $\left(U_{D}\right)$, gross assimilatory uptake rate by phytoplankton $\left(U_{A, P}\right)$, and by benthic algae $\left(U_{A, B}\right)$

$U_{\text {GROSS }}=U_{D}+U_{A, P}+U_{A, B}$ 
The net uptake rate was calculated by subtracting the DIN release rates by phytoplankton $\left(R_{P}\right)$, benthic algae $\left(R_{B}\right)$, and mineralization $\left(U_{M I M}\right)$ from $U_{G R O S S}$ as

$U_{N E T}=U_{D}+U_{A, P}+U_{A, B}-R_{P}-R_{B}-U_{M I N}$

The percentage gross uptake of total input loading $\left(E_{G R O S S}\right.$, in \%) and the percentage net uptake $\left(E_{N E T}\right.$, in \%) were calculated

$E_{\text {GROSS }}=\frac{U_{G R O S S} \times A \times 10^{-6}}{I} \times 100 \%$

$E_{N E T}=\frac{U_{N E T} \times A \times 10^{-6}}{I} \times 100 \%$

195 where $A$ represents the riverbed area of the study reach in $\mathrm{m}^{2} ; I$ represents the total DIN input in $\mathrm{kg} \mathrm{d}^{-1} ; 10^{-6}$ is the unit converter from $\mathrm{mg} \mathrm{d}^{-1}$ to $\mathrm{kg} \mathrm{d}^{-1}$. The net assimilatory uptake rates by phytoplankton $\left(U_{N E T, A, P}\right)$ and by benthic algae $\left(U_{N E T, A, B}\right)$ were calculated by subtracting release rates from gross uptake rates.

$U_{N E T, A, P}=U_{A, P}-R_{P}$

$U_{N E T, A, B}=U_{A, B}-R_{B}$

For better comparing the uptake rate results of this study with others, we calculated the $\mathrm{NO}_{3}{ }^{-}$gross and net uptake rate $\left(U_{G R O S S, N O 3} \& U_{N E T, N O 3}\right)$ and $\mathrm{NH}_{4}{ }^{+}$gross and net uptake rate $\left(U_{G R O S S, N H 4} \& U_{N E T, N H 4}\right)$ separately (detailed description in SI Text2).

\section{Results}

\subsection{Modeling performance and physio-chemical characteristics}

205 The parameter sensitivity ranking results showed that the parameters related to benthic algae metabolism, including $\mathrm{F}_{\mathrm{Gb} 20}, \rho_{\mathrm{mN}}$, $\mathrm{K}_{\mathrm{Lb}}, \mathrm{K}_{\mathrm{hn \times b}}, \mathrm{k}_{\mathrm{Db} 20}, \mathrm{~K}_{\mathrm{qN}}, \mathrm{k}_{\mathrm{Rb} 20}, \mathrm{f}_{\mathrm{ONb}}, \mathrm{k}_{\mathrm{Eb} 20}$ and $\theta_{\mathrm{Eb} 20}$, influenced the goodness-of-fit of measured and simulated $\mathrm{NH}_{4}{ }^{+}$and $\mathrm{NO}_{3}{ }^{-}$ the most (Fig. S2, Table 2). Following those, the parameters related to denitrification and phytoplankton processes, including $k_{d n i t}$ and $k_{G \max }$, were also screened as the identifiable parameters (Fig. S2). The most sensitive parameters for simulating N dynamics are related to benthic algae and phytoplankton turnover and denitrification.

210 Table 2. Identifiable parameters related to DIN processing and their optimized values.

\begin{tabular}{lllll}
\hline Symbol & Kinetic Constant & Units & Value $^{\text {Range }^{1}}$ \\
\hline $\mathrm{F}_{\mathrm{Gb} 20}$ & Benthic algae maximum growth rate & $\mathrm{gD} \mathrm{m}^{-2} \mathrm{~d}^{-1}$ & 6.5 & $5-100$ \\
$\rho_{\mathrm{mN}}$ & Maximum N uptake rate for benthic algae & $\mathrm{mgN} / \mathrm{gD}-\mathrm{d}$ & 720 & $200-2000$ \\
$\mathrm{~K}_{\mathrm{Lb}}$ & Light constant for benthic algal growth & $\mathrm{Ly} \mathrm{d}^{-1}$ & 130 & $50-300$ \\
$\mathrm{~K}_{\mathrm{hnxb}}$ & Ammonia preference for benthic algae & $\mathrm{mg} \mathrm{N} \mathrm{L}$ & 0.025 & $0.01-0.5$
\end{tabular}


https://doi.org/10.5194/hess-2021-615

Preprint. Discussion started: 19 January 2022

(C) Author(s) 2022. CC BY 4.0 License.

(c) (P)
Hydrology and

Earth System

Sciences

Discussions

\begin{tabular}{|c|c|c|c|c|}
\hline $\mathrm{k}_{\mathrm{Db} 20}$ & Benthic algae death rate constant & $\mathrm{d}^{-1}$ & 0.02 & $0.001-0.2$ \\
\hline $\mathrm{K}_{\mathrm{qN}}$ & Half saturation uptake constant for benthic algae intracellular $\mathrm{N}$ & $\mathrm{mgN} / \mathrm{gD}$ & 9 & $5-20$ \\
\hline $\mathrm{k}_{\mathrm{Rb} 20}$ & Benthic algae respiration rate constant & $\mathrm{d}^{-1}$ & 0.2 & $0.05-0.2$ \\
\hline$f_{\mathrm{ONb}}$ & Fraction of benthic algae recycled to organic $\mathrm{N}$ & -- & 0.21 & $0-0.5$ \\
\hline $\mathrm{k}_{\mathrm{Eb} 20}$ & Internal nutrient excretion rate constant for benthic algae & $\mathrm{d}^{-1}$ & 0.1 & $0.02-0.1$ \\
\hline$\theta_{\mathrm{Eb} 20}$ & Temperature coefficient for benthic algal nutrient excretion & -- & 1.05 & $1.05-1.08$ \\
\hline $\mathrm{k}_{\text {dnit }}$ & Denitrification rate constant at $20^{\circ} \mathrm{C}$ & $\mathrm{d}^{-1}$ & 0.15 & $0-0.4$ \\
\hline $\mathrm{k}_{\mathrm{Gmax}}$ & Phytoplankton maximum growth rate constant at $20^{\circ} \mathrm{C}$ & $d^{-1}$ & 2.5 & $0.5-4.0$ \\
\hline
\end{tabular}

${ }^{1}$ Sources of literature values: Wool et al. (2002) and Martin et al. (2017).

The optimized model parameters using automatic calibration are presented in Table 2. Simulation results of $\mathrm{Q}, \mathrm{NO}_{3}{ }^{-}, \mathrm{DO}$ and Chl-a and the corresponding evaluation criteria for calibration (2 years) and validation periods ( 3 years) were shown in Fig. 2 and Table 3. The PBias was lower than 5\% and NSE was higher than 0.90 between the simulated and measured high215 frequency data of $\mathrm{Q}, \mathrm{NO}_{3}{ }^{-}$, and $\mathrm{DO}$ for both periods (Table 3). Our Chl-a simulation results captured the timing of blooms, peaks, and decline of phytoplankton (Fig. 2d). The NSE of Chl-a was relatively low partly due to the leverage effect of missing the extreme high Chl-a concentrations only on some days during the bloom periods on the overall performance criteria. The underestimation of the spring bloom peaks during the validation period is due to the compensation of reproducing the spring peaks using the same set of parameters during the calibration period. The WASP model simulations of $\mathrm{NH}_{4}{ }^{+}, \mathrm{PO}_{4}{ }^{3-}$, and Carbonous BOD (CBOD) also mimicked the seasonality well (Fig. 2e, S3, and Table 3). 

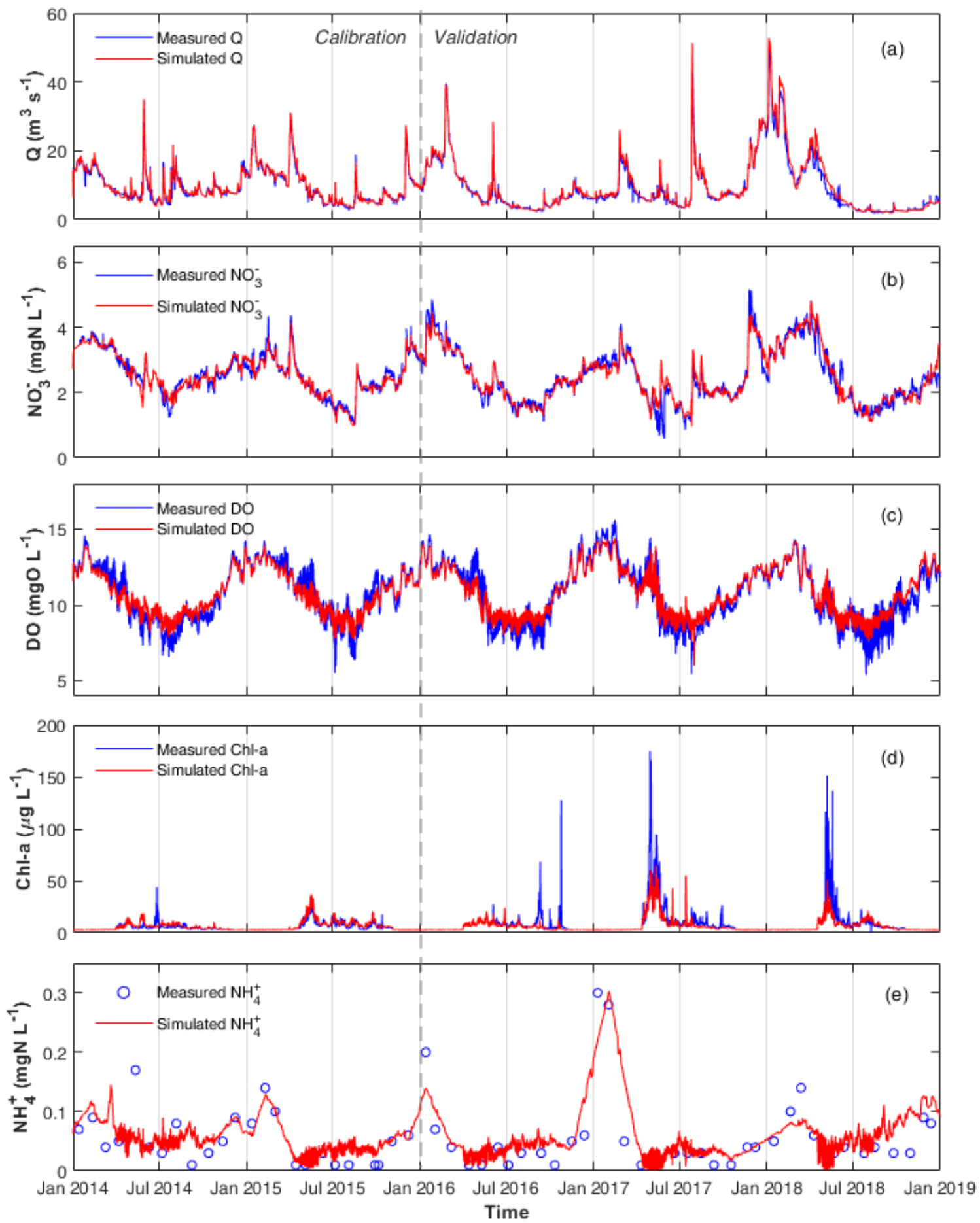

Figure 2. Measured and simulated (a) $\mathrm{Q}$ (b) $\mathrm{NO}_{3}{ }^{-}$(c) $\mathrm{DO}$ (d) $\mathrm{Chl}$-a and (e) $\mathrm{NH}_{4}{ }^{+}$concentrations in the calibration and validation periods at the STF station. 
Table 3. Statistics of measurements and model evaluation criteria (NSE, RMSE, and PBIAS) of model calibration and validation results at the STF station of Lower Bode River.

\begin{tabular}{llllllllll}
\hline & \multicolumn{3}{l}{ Measurement Statistics } & \multicolumn{3}{l}{ Calibration (2014-2015) } & \multicolumn{3}{c}{ Validation (2016-2018) } \\
\cline { 2 - 9 } & Unit & Mean & SD & NSE & PBIAS (\%) & RMSE & NSE & PBIAS (\%) & RMSE \\
\hline Q & $\mathrm{m}^{3} \mathrm{~s}^{-1}$ & 9.58 & 6.78 & 0.97 & 0.85 & 0.08 & 0.98 & 4.48 & 0.42 \\
$\mathbf{N O}^{-}$ & $\mathrm{mgN} \mathrm{L}^{-1}$ & 2.50 & 0.77 & 0.93 & -0.45 & 0.01 & 0.91 & 1.16 & 0.03 \\
$\mathbf{D O}$ & $\mathrm{mg} \mathrm{L}^{-1}$ & 10.74 & 1.92 & 0.90 & 0.12 & 0.01 & 0.92 & -0.11 & 0.04 \\
$\mathbf{C h l - a}$ & $\mathrm{\mu g} \mathrm{L}^{-1}$ & 10.25 & 13.15 & 0.45 & 19.04 & 1.28 & 0.53 & -28.85 & 3.79 \\
$\mathbf{N H}_{4}{ }^{+}$ & $\mathrm{mgN} \mathrm{L}^{-1}$ & 0.06 & 0.06 & 0.42 & 16.52 & 0.01 & 0.75 & 22.91 & 0.01 \\
$\mathbf{G P P}^{-}$ & $\mathrm{mgO} \mathrm{L}^{-1}$ & 0.65 & 0.86 & 0.23 & -6.96 & 0.06 & 0.45 & -8.60 & 0.08 \\
$\mathbf{P O}_{4}{ }^{3-}$ & $\mathrm{mgP} \mathrm{L}^{-1}$ & 0.04 & 0.02 & 0.73 & 11.96 & 0.01 & 0.80 & 6.98 & 0.003 \\
$\mathbf{C B O D}^{-1}$ & $\mathrm{mgO} \mathrm{L}^{-1}$ & 4.60 & 0.71 & 0.17 & -13.99 & 0.30 & 0.17 & -14.75 & 0.33 \\
\hline
\end{tabular}

A clear seasonal pattern of Q can be observed, with higher values in winter and lower ones in summer (Fig. 2a). Q averaged $9.58 \mathrm{~m}^{3} \mathrm{~s}^{-1}$, with a minimum of $2.05 \mathrm{~m}^{3} \mathrm{~s}^{-1}$ during the extreme low-flow in August 2018 and a maximum of $49.49 \mathrm{~m}^{3} \mathrm{~s}^{-1}$ during winter high flow in January 2018 (Table 3, Fig. 2a). $\mathrm{NO}_{3}{ }^{-}$concentration was higher in winter when Q was high and lower in summer when Q was low (range 0.57-5.15 and mean $2.50 \mathrm{mg} \mathrm{N} \mathrm{L}{ }^{-1}$; Fig. 2b). By comparing the concentrations of $\mathrm{NH}_{4}{ }^{+}$and $\mathrm{NO}_{3}{ }^{-}$, we found that $\mathrm{NO}_{3}{ }^{-}$was the dominant form of DIN in the Lower Bode, accounting for more than $97 \%$ of total DIN (calculated according to their mean values in Table 3). DO concentrations were higher in winter and lower in summer (range 5.40-15.63 and mean $10.74 \mathrm{mg} \mathrm{L}^{-1}$; Fig. 2c). Oxygen daily amplitudes were most pronounced during the spring phytoplankton bloom period (compared with Fig. 2d) and the summer low-flow period. In the extreme summer low-flow period of 2018 (validation period), simulated DO amplitudes were smaller than the measured ones, indicating an underestimation of primary production. Phytoplankton blooms were observed in spring between April and late May, especially in 2017 and 2018, with peak concentrations of Chl-a higher than $150 \mu \mathrm{g} \mathrm{L}^{-1}$ (Fig. 2e).

Simulated GPP from WASP reflected those calculated by the single station method (Fig. 3, Table 3). GPP showed two seasonal peaks each year, one in spring and one in summer (Fig. 3a). The first peak in spring corresponded to the peak of phytoplankton Chl-a concentrations (Fig. 2d), while the other corresponded to the peak of benthic algae biomass (Fig. S3c). Accordingly, the model results showed that GPP was dominated by phytoplankton growth in spring, while in summer, GPP was controlled by benthic algae (Fig. 3b). 

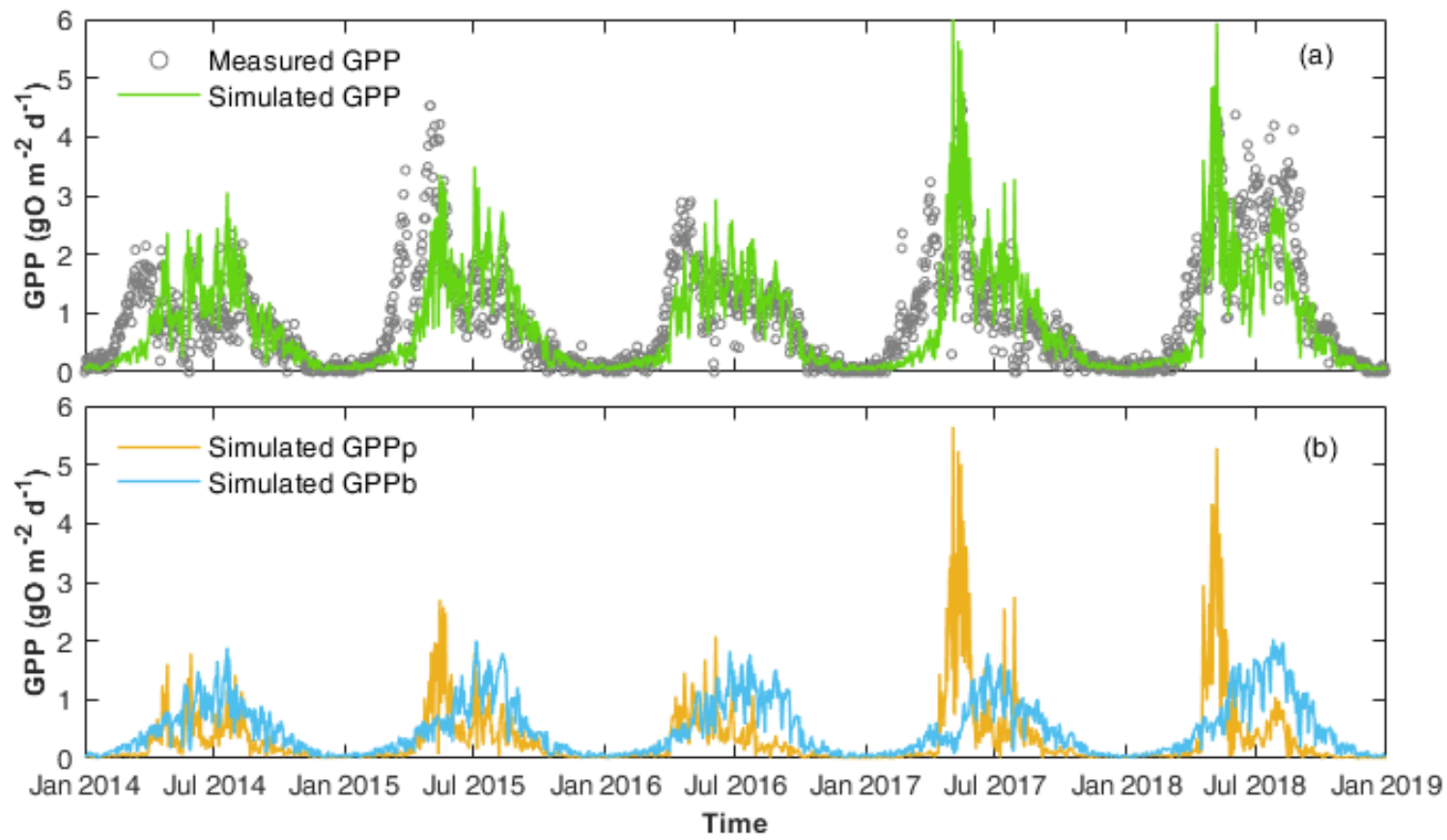

Figure 3. (a) Comparison of the daily GPP calculated by WASP (simulated GPP) and by the single-station method (measured GPP); (b) Two components of simulated GPP, i.e., GPP by phytoplankton (GPPp) and by benthic algae $\left(\right.$ GPP $\left._{b}\right)$.

\subsection{Daily DIN uptake rates}

Daily DIN gross uptake rate $\left(U_{\text {GROSS }}\right)$ averaged 124.1 and ranged from 7.9 to $707.9 \mathrm{mg} \mathrm{N} \mathrm{m}^{-2} \mathrm{~d}^{-1}$. Net uptake rate $\left(U_{N E T}\right)$ averaged 56.8 and ranged from -17.4 to $553.9 \mathrm{mg} \mathrm{N} \mathrm{m}^{-2} \mathrm{~d}^{-1}$ (Table S3). Contrary to the seasonal trends of $\mathrm{NO}_{3}{ }^{-}$and $\mathrm{NH}_{4}{ }^{+}$ concentrations, higher $U_{G R O S S}$ and $U_{N E T}$ were primarily found in spring and summer, whereas the rates were lower in autumn and winter, even with negative $U_{N E T}$ (Fig. $4 \mathrm{a} \& 4 \mathrm{~b}$ ). The highest two peak values appeared in the spring of 2017 and 2018 when phytoplankton bloomed, and the Chl-a level peaked (Fig. 4a \& 4b). The $U_{G R O S S}$ and $U_{N E T}$ increased significantly with the bloom formations and dropped with their vanishing. In summer, $U_{N E T}$ were high most of the time until it decreased towards September (Fig. 4b). The negative values of $U_{N E T}$ in autumn and winter showed that the river reach released net DIN.

Percentage daily net uptake $\left(E_{N E T}\right)$ peaked at $29.1 \%$ during the extreme summer low flow of August 2018 (Fig. 4c). Consistent with the uptake rate, $E_{N E T}$ was also higher in spring and summer and lower in autumn and winter. However, the efficiencies in summer were generally even higher than those in spring because of the lower DIN loading in summer (Fig. 4c).

The variability of daily net uptake rate by phytoplankton $\left(U_{N E T, A, P}\right)$ was more extensive than that of benthic algae $\left(U_{N E T, A, B}\right)$ (Fig. $4 \mathrm{e} \& 4 \mathrm{f}$ ). We observed constant negative $U_{N E T, A, B}$ in autumn and winter when $R_{B}$ was higher than $U_{A, B} . U_{N E T, A, P}$ was also negative but closer to zero compared with $U_{N E T, A, B}$ in autumn and winter. Daily denitrification rate $\left(U_{D}\right)$, as the only $\mathrm{N}$ removal process, averaged $14.1 \mathrm{mg} \mathrm{N} \mathrm{m}^{-2} \mathrm{~d}^{-1}$ and ranged from 0.2 to $117.1 \mathrm{mg} \mathrm{N} \mathrm{m}^{-2} \mathrm{~d}^{-1}$ (Fig. $4 \mathrm{~d}$ ). 
https://doi.org/10.5194/hess-2021-615

Preprint. Discussion started: 19 January 2022

(c) Author(s) 2022. CC BY 4.0 License.
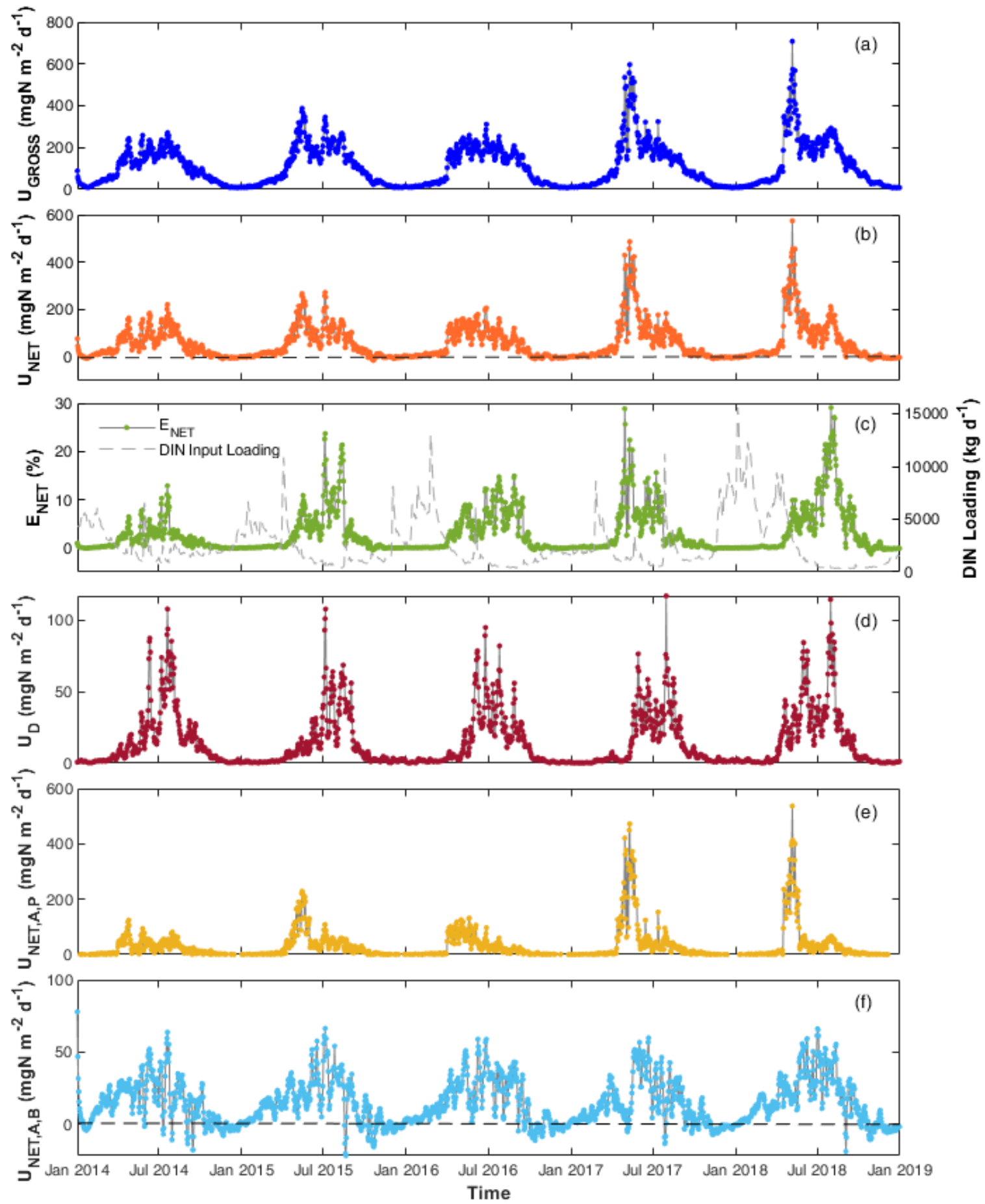

Figure 4. Daily (a) gross uptake rate $\left(U_{G R O S S}\right)$, (b) DIN net uptake rate $\left(U_{N E T}\right)$, (c) percentage net uptake $\left(E_{N E T}\right)$, (d) denitrification rate $\left(U_{D}\right)$, (e) net uptake rate by phytoplankton $\left(U_{N E T, A, P}\right)$, and (f) by benthic algae $\left(U_{N E T, A, B}\right)$ in the Lower Bode River (2014-2018). Black dash lines in (b) and (f) are zero lines to better show that net $\mathrm{N}$ uptake is often negative in autumn and winter. 


\subsection{Seasonal and multi-annual pattern of DIN uptake}

DIN fluxes exhibited evident seasonal variation with the highest loadings in winter, accounting for more than half of the total fluxes of the year (Table 4). The seasonal rankings of both averaged DIN gross and net uptake rates were: summer > spring > autumn > winter (Table 4). In spring, both the DIN gross and net uptake were dominated by the phytoplankton uptake pathway. In summer, benthic algae assimilation dominated the gross DIN uptake. However, its contribution to net uptake was limited due to the elevated excretion rate by higher temperatures. Besides, the denitrification rate increased significantly in summer, accounting for $16.7 \%$ of the gross uptake in summer. Thus, the three DIN processing pathways contributed similar shares of net DIN uptake. It should be noted that the averaged net DIN uptake by benthic algae was found to be positive in autumn and winter despite many negative daily values. One explanation is that the net uptake was calculated from the perspective of DIN. In the WASP model, algae uptake uses two forms of $\mathrm{N}$ source, i.e., $\mathrm{NH}_{4}{ }^{+}$and $\mathrm{NO}_{3}{ }^{-}$, and they excrete in the two forms of DON and $\mathrm{NH}_{4}{ }^{+}$. The organic fraction of excreted $\mathrm{N}$ ( $f_{\mathrm{ONb}}$, Table 2$)$ for benthic algae was set to 0.21 in the model after calibration. From the perspective of reactive $\mathrm{N}$ (DIN+DON, $\mathrm{N}_{\mathrm{r}}$ ), benthic algae played the role of $\mathrm{N}_{\mathrm{r}}$ source in autumn $(48.6 /(1-0.21)>$ 52.3).

5-Year average $U_{\text {GROSS }}$ and $U_{N E T}$ were 124.1 and $56.8 \mathrm{mg} \mathrm{N} \mathrm{m}^{-2} \mathrm{~d}^{-1}$, respectively. On a 5-year basis, gross uptake accounted for $2.7 \%$ of total DIN input loading, and net uptake accounted for $1.2 \%$ of total loading of the study reach in the Lower Bode. $U_{\text {GROSS }}$ via different pathways ranked as assimilatory uptake by benthic algae $\left(72.6 \mathrm{mg} \mathrm{N} \mathrm{m}^{-2} \mathrm{~d}^{-1}\right)>$ assimilatory uptake by phytoplankton (37.2 $\left.\mathrm{mg} \mathrm{N} \mathrm{m}^{-2} \mathrm{~d}^{-1}\right)>$ denitrification $\left(14.3 \mathrm{mg} \mathrm{N} \mathrm{m}^{-2} \mathrm{~d}^{-1}\right)$. In contrast, $U_{N E T}$ ranked as phytoplankton net uptake $\left(28.5 \mathrm{mg} \mathrm{N} \mathrm{m}^{-2} \mathrm{~d}^{-1}\right)>$ benthic algae net uptake $\left(14.6 \mathrm{mg} \mathrm{N} \mathrm{m}^{-2} \mathrm{~d}^{-1}\right)>$ denitrification $\left(14.3 \mathrm{mg} \mathrm{N} \mathrm{m}^{-2} \mathrm{~d}^{-1}\right)$.

Table 4. Seasonal DIN budget including inputs, outputs, and process rates in the Lower Bode (average results from 2014 to 2018 ).

\begin{tabular}{|c|c|c|c|c|c|}
\hline & Spring & Summer & Autumn & Winter & 5-Y Mean \\
\hline GGL & 2681 & 1117 & 1178 & 5493 & 2617 \\
\hline Tributaries & 384 & 115 & 117 & 518 & 284 \\
\hline$\Sigma$ Inputs & 3065 & 1232 & 1295 & 6011 & 2901 \\
\hline \multicolumn{6}{|l|}{ DIN Process Rates $\left(\mathrm{mg} \mathrm{N} \mathrm{m}^{-2} \mathrm{~d}^{-1}\right)$} \\
\hline Denitrification & 9.9 & 39.0 & 6.8 & 1.4 & 14.3 \\
\hline Assimilatory uptake by phytoplankton & 89.4 & 46.0 & 9.8 & 3.8 & 37.2 \\
\hline Assimilatory uptake by benthic algae & 72.7 & 149.0 & 52.3 & 16.6 & 72.6 \\
\hline Mineralization & 0.2 & 1.7 & 0.4 & 0.03 & 0.6 \\
\hline DIN gross uptake & 172.0 & 234.0 & 68.9 & 21.7 & 124.1 \\
\hline
\end{tabular}




\section{Discussion}

\subsection{Seasonal role shift and multi-annual performance}

285 The DIN gross and net uptake rates in the Lower Bode showed large seasonal variability. $85 \%$ of gross and $91 \%$ of net uptake occurred in the growing seasons, i.e., spring and summer. Thus, the uptake during the growing season dominates the annual uptake amount. $U_{N E T, N O 3}$ in the growing season in the Lower Bode are comparable to those measured in rivers of similar size from other studies, e.g., Weiße Elster in Germany (Kunz et al., 2017) and 6 subtropical streams in Florida (Hensley et al., 2014) (more comparison in SI Text 3).

Starting from autumn in October, net releases began to appear, and the DIN net release rate could reach $17.4 \mathrm{mg} \mathrm{N} \mathrm{m}^{-2} \mathrm{~d}^{-1}$. The net release phenomenon can last until January of the following year. It is worth noting that the net release phenomenon was rarely reported in previous studies (von Schiller et al., 2015). One important reason is most previous measurements were taken by snapshot experiments, which were mainly conducted in the growing season with high biological activity (Mulholland et al., 2008). Still, knowing the net release rate and timing of the shift is also essential. As the net release occurs in the Lower Bode only in autumn and winter, they may not boost downstream ecosystem productivity as the light availability and temperatures are not favorable in these seasons. The reliable estimation of instream DIN release and timing of the functional shift from net uptake to release can benefit from continuous high-frequency measurements.

The net release is caused by the DIN excretion by primary producers (mainly benthic algae) overpassed the denitrification and assimilatory uptake. Excretion occurs the whole growing season, but it is more than balanced by denitrification and assimilatory uptake. In autumn, the two removal processes are losing importance which leads to a net release. It is challenging to observe the net release from a short-term observation (hours) because $\mathrm{N}$ has a round-trip ticket to the benthic algae, and the net $\mathrm{N}$ uptake can be a quasi-equilibrium (von Schiller et al., 2015). Estimates of the flux of immobilized $\mathrm{N}$ back to the water column in the non-growing season have been overlooked for a long time (von Schiller et al., 2015; Riis et al., 2012; Tank et al., 2018). Still, it is critical for our understanding of the entire instream $\mathrm{N}$ processing.

Analyzing the seasonality of DIN uptake can help us understand its yearly performance. The 5-year average $E_{N E T}$ in the Lower Bode was only $1.2 \%$ despite the highest percentage being close to $30 \%$. The low overall removal percentage was because most DIN inputs occurred during high flow periods when hydraulic conditions, temperatures, and light were less favourable for instream uptake processes. Moreover, there is also a seasonal shift to net release in an annual cycle. From this study, we learned that simple aggregation of instream DIN uptake from snapshot experiment results in the growing season might cause significant uncertainties in estimating the role of streams in annual DIN uptake. 


\subsection{Benthic algae and phytoplankton uptake pathways}

The DIN assimilation by benthic algae accounts for 59\% of the annual gross uptake of the Lower Bode (Table 4). In contrast, the net DIN uptake by phytoplankton dominates the annual net uptake of the Lower Bode (50\%). Our results showed that assimilatory DIN uptakes by phytoplankton and benthic algae both play an essential role in the annual DIN uptake budget in the Lower Bode. The $6^{\text {th }}$ order Lower Bode belongs to the mid-reach river system with a transitional size between small streams and large rivers. In the $4^{\text {th }}$ order stream Selke upstream of Bode (Fig. 1), benthic algae dominates the assimilatory DIN uptake (Rode et al., 2016a). In contrast, in the $8^{\text {th }}$ order River Elbe downstream of Bode, phytoplankton dominates the assimilatory DIN uptake (Kamjunke et al., 2021). In the transitional $6^{\text {th }}$ order Lower Bode, phytoplankton gains importance in DIN assimilation. Still, both phytoplankton and benthic algae play a critical overlapping role in assimilatory DIN uptakes at this stream order.

The shift of assimilatory DIN uptake from benthic algae-dominated to phytoplankton-dominated across stream orders well demonstrates the River Continuum Concept (RCC). According to the RCC, mid-reach river systems are broader, deeper, and less strongly influenced by dilution. Autochthonous primary production can occur through planktonic (typically stream order 5-7) development (Durand et al., 2011; Vannote et al., 1980). Recently, Yang et al. (2021) provided evidence of a regime shift in algal biomass over stream-order. Our results further supplemented the algal role transition in terms of DIN uptake along with the river network.

Despite both important roles for annual assimilatory DIN uptake, phytoplankton and benthic algae had different dominant seasons, determined by their characteristics and interaction. Phytoplankton formed outbreaks in spring, usually May, especially in 2017 and 2018, whereas benthic algae biomass peaks in the midsummer, typically July. The spring phytoplankton peaks are often observed in many large rivers, e.g., the Elbe, Rhine (Hardenbicker et al., 2014), and Danube (Reynolds and Descy, 1996). The formation of the spring bloom is suggested to be related to the seasonal changes in solar irradiation, water temperature, nutrient availability, and flow condition (Reynolds and Descy, 1996). The dominant taxa of phytoplankton were identified as diatoms in the Lower Bode (Kamjunke et al., 2015). The average phytoplankton Chl-a levels in the Lower Bode reached the highest when the water temperature was between $10-14{ }^{\circ} \mathrm{C}$ (Fig. S4), which fits the optimal growth temperature of diatoms (Chapra, 2008). As the light availability and other conditions were also favourable in spring, phytoplankton bloomed, consequently assimilating large amounts of DIN. The spring phytoplankton peak is believed to be suppressed by the increasing grazing zooplankton (Sommer et al., 2012).

In contrast with phytoplankton, benthic algae had the highest biomass and DIN assimilatory uptake in July. Similar seasonal peaking time of benthic algae was also found in other rivers (Glasaite and Šatkauskienè, 2013). The development of benthic

340 algae in summer can be explained by the different environmental factors such as increasing temperature, decreasing turbulence, and grazing during the summer months (Glasaitė and Šatkauskienė, 2013, Jäger and Borchardt, 2018). Note that here benthic algae refer to the whole primary producer community in benthic habitats in our model, where we did not distinguish periphyton and macrophytes. Periphyton is recognized as dominant in the benthic habitats in the study reach, despites some macrophytes 
to a small partition (LHW, 2002). Although the newest version of WASP8 can describe them separately (Wool et al., 2020),

we prioritized avoiding introducing more model parameters by increasing the model structure complexity, but without sufficient data to identify in our modelling practice.

The differences between phytoplankton and benthic algae in DIN assimilation were also reflected in the characteristic time. The DIN uptake by phytoplankton was 'acute,' while uptake by benthic algae was 'chronic' (day-week vs. month-years) (Lepoint et al., 2004). The phytoplankton biomass can be temporally very dynamic. It can increase rapidly under favorable conditions within days to weeks in the blooming phase assimilating massive DIN within a short period. Due to the high dynamics of phytoplankton, paired high-frequency monitoring data can better define boundaries of seeds and capture instream growth rates, ensuring a high-accuracy estimation of DIN assimilation. Nevertheless, because of the difficulties inherent in the use of high-frequency chlorophyll fluorescence signal as indirect measures of phytoplankton biomass and lack of direct measurements (Hamilton et al., 2015), uncertainty still exists in the estimation results. In contrast, the biomass change of benthic algae is suggested to be gradual and continuous unless disturbance (Jäger and Borchardt, 2018; Rimet et al., 2015). The DIN uptake or release by benthic algae is closely related to the changes in their biomass. More measurements of benthic algae biomass across seasons are strongly recommended to support the estimation of the assimilatory DIN uptake via benthic algae with more evidence.

The DIN assimilation by phytoplankton and benthic algae showed another significant difference in terms of gross vs. net uptake. On a 5-Year average basis, the net DIN uptake by phytoplankton was 77\% of its gross uptake in the Lower Bode, while the net DIN uptake by benthic algae was only $20 \%$ of its gross uptake (Table 4 ). The difference is mainly because the phytoplankton can be transported downstream beyond the study reach, while the benthic algae are fixed in the river bottom in the reach. The assimilated DIN by phytoplankton can be transported out of the reach before it has enough residence time to release. Consequently, massive gross and net uptake in the study reach can be observed simultaneously during the spring phytoplankton blooming phase in the Lower Bode. In contrast, the uptake and excretion of $\mathrm{N}$ by the benthic algae is happening simultaneously within the study reach as the assimilated $\mathrm{N}$ does not move downstream like in phytoplankton. Besides, benthic algae's biomass completes a cycle on a yearly basis. Large amounts of $\mathrm{N}$ assimilated and stored in the benthic algae during the growing season will be released back into the waters after they die. In the end, although the gross uptake by benthic algae was higher than by phytoplankton yearly, its net uptake was lower than by phytoplankton at the reach scale (Table 4). Note that our release calculations are conservative estimates because we were not able to measure particulate $\mathrm{N}$ release for the stream reach. Specifically, during higher flows, benthic algae and particulate $\mathrm{N}$ can be scored from the stream bottom and carried downstream out of our study reach (Jäger and Borchardt, 2018).

However, the high DIN net uptake via phytoplankton does not mean DIN is completely removed from the riverine system. Phytoplankton can settle and become a nutrient source downstream. On the other hand, the low net uptake via benthic algae does not mean that they do not play an essential role in instream $\mathrm{N}$ processing. Although the assimilated $\mathrm{N}$ by phytoplankton and benthic algae is temporarily stored in their biomass pools and eventually sustains the nutrient spiral downstream in different forms of $\mathrm{N}$, their uptake contributes to downstream water quality by retarding $\mathrm{N}$ downstream transport before denitrification 
or ultimate burial (Hall et al., 2009). This downstream impact is not restricted to $\mathrm{N}$ but is also valid for phosphorus (P). Due to the stable stoichiometric N:P relationship in benthic algae (Redfield, 1958; Rutherford et al., 2020), we can assume that

nutrient uptake is also valid for $\mathrm{P}$. Therefore, temporal sequestration and associated turnover time delays the downstream transport of nutrients (Ensign and Doyle, 2006) and can lower available downstream P in ecologically relevant spring and summer periods. Our results show that $\mathrm{N}$ is strongly released from biomass during less biologically active periods in autumn and early winter, and this is likely also the case for P.

\subsection{The value of using high-frequency data in quantifying $N$ pathways}

This study improved confidence in quantifying the instream $\mathrm{N}$ processes using a combination of high-frequency data and a water quality model from several aspects. First, the synchronous continuous high-frequency $\mathrm{NO}_{3}{ }^{-}$and $\mathrm{Q}$ data accurately defines upper boundary conditions for DIN external loadings. DIN fluxes are highly uneven in time, and a significant fraction of yearly export occurs during a few high flow events (Hensley et al., 2019). Therefore, missing some high flux events may cause a significant deviation in estimating the DIN uptake in the model, especially on multi-annual scales.

Second, the GPP from model results can be validated by calculated GPP through high-frequency DO measurements. Recent work suggests that nutrient fluxes are large relative to autotrophic demand in streams that are no longer N-limited (Covino et al., 2018). Thus, validation of simulated GPP is vital to constrain the model parameterization of assimilatory uptake processes.

Third, paired high-frequency Chl-a data enabled us to approximate the growth rate of phytoplankton. Based on the total GPP and phytoplankton GPP, the assimilatory DIN uptakes by phytoplankton and benthic algae are disentangled with more evidence.

Fourth, the downstream high-frequency $\mathrm{NO}_{3}{ }^{-}$concentration signal is a synthesis of upstream delivery and internal biogeochemical processing signals. By ascertaining the external loading and fluxes of assimilatory uptake processes, the denitrification rate can be well constrained in the model. Especially in the summer low-flow period, the $\mathrm{NO}_{3}{ }^{-}$simulation is sensitive to denitrification because it accounts for over $30 \%$ of the net uptake in the Lower Bode. Note that this $\mathrm{NO}_{3}{ }^{-}$removal can be dedicated to the sum of denitrification plus heterotrophic uptake. As heterotrophic uptake is not described in the WASP, these two processes cannot be disentangled.

Finally, a continuous estimation of DIN processing via multiple pathways in the Lower Bode was achieved by incorporating high-frequency data into water quality modeling. The significance of our study lies in the overarching picture of the $\mathrm{N}$ processing in a $6^{\text {th }}$ order agricultural stream, which deepens our systematic insights into the processes and facilitates our ability to manage aquatic systems.

\section{Conclusions}

High-frequency data from autonomous sensors offer an opportunity to align observations and simulations from a water quality model. The combination of model and high-frequency data has great potential to deliver the long-needed inference about 
continuous quantification of instream DIN processing pathways. In this study, we mimicked the patterns of $\mathrm{Q} \mathrm{NO}_{3}{ }^{-}$, and $\mathrm{DO}$

with the NSE values of higher than 0.9 in the Lower Bode using the WASP EUTRO model. This is one of the few model testings with both simulated and measured state variables at such high temporal resolution (15-min interval). On this basis, our model could adequately infer continuous DIN processing, including denitrification, assimilatory uptake and release pathways at daily, seasonal and multi-annual scales and the three research questions could be answered. The daily DIN net uptake rates were highly temporally variable, ranging from $-17.4 \mathrm{mg} \mathrm{N} \mathrm{m}^{-2} \mathrm{~d}^{-1}$ to $553.9 \mathrm{mg} \mathrm{N} \mathrm{m}^{-2} \mathrm{~d}^{-1}$. Seasonal role shifts of the Lower Bode from $\mathrm{N}$ net sink to source was captured and the dominating process causing this shift, namely net $\mathrm{N}$ release from benthic algae in the non-growing season, was quantified. Based on the continuous DIN budget across 5 years, the percentage gross uptake in the Lower Bode was only $2.7 \%$, which was dominated by benthic algae assimilation, followed by phytoplankton assimilation and denitrification. Our results demonstrate the WASP EUTRO model's ability to estimate DIN processing pathways in a large agricultural lowland stream where benthic algae and phytoplankton co-exist. The long-term high-frequency data increased the reliability of the process estimation from the model through both state and process validations. Nevertheless, in different aquatic systems, the dominant $\mathrm{N}$ processing pathways may be different. If the high-frequency measurements happen to have discrepancies with model results in other systems, it also provides an opportunity to identify the mechanisms that may be incompletely represented in the model formulation. In the end, the approach of combining models with highfrequency measurements provides a tool to drive forward more rigorous model assessment and process representation. The resulting improvements in model process representation and performance provide opportunities to move beyond quantifying current snapshot instream $\mathrm{N}$ processes and into a domain of dynamic continuous estimation and prediction.

\section{Data availability}

The high-frequency water quality from the sensors used in this study are archived in the TERENO database and available for the scientific community upon request through the TERENO-Portal (www.tereno.net/ddp). The discharge data are freely available and downloadable from the data portal of the State Office of Flood Protection and Water Quality of Saxony-Anhalt (https://gld-sa.dhi-wasy.de/GLD-Portal/). The water quality data of the tributaries are also downloadable from the same portal. The hourly solar radiation data can be downloaded from open data portal of German Meteorological Service (https://opendata.dwd.de/).

\section{Author contribution}

$435 \mathrm{JH}$ : conceptualization, methodology, software, validation, formal analysis, investigation, writing- original draft preparation, visualization. DB: resources, writing- reviewing and editing, funding acquisition. MR: data curation, writing- reviewing and editing, supervision, project administration. 


\section{Acknowledgements}

We thank the flood protection and water management agency of the state of Saxony-Anhalt, Germany (LHW), for providing data on water discharge and routine water quality data. We also thank the TERENO (Terrestrial Environmental Observatories) project to support the high-frequency monitoring in Lower Bode and Uwe Kiwel to maintain the sensor measurements. J. Huang would like to thank the financial support from the CSC-DAAD Postdoc Fellowship.

\section{Competing interests}

The authors declare that they have no conflict of interest.

\section{References}

Burgin, A.J. and Hamilton, S.K.: Have we overemphasized the role of denitrification in aquatic ecosystems? A review of nitrate removal pathways, Front. Ecol. Environ., 5(2), 89-96, https://doi.org/10.1890/15409295(2007)5[89:HWOTRO]2.0.CO;2, 2007.

Chapra, S.C.: Surface water-quality modeling, Waveland press, Long Grove, IL, US, 2008.

450 Covino, T.P., Bernhardt, E.S., and Heffernan, J.B.: Measuring and interpreting relationships between nutrient supply, demand, and limitation, Freshw. Sci., 37(3), 448-455, https://doi.org/10.1086/699202, 2018.

Ensign, S.H. and Doyle, M.W.: Nutrient spiraling in streams and river networks, J. Geophys. Res. Biogeosci., 111, G04009, https://doi.org/10.1029/2005JG000114, 2006.

Durand, P., Breuer, L., Johnes, P.J., Billen, G., Butturini, A., Pinay, G., van Grinsven, H., Garnier, J., Rivett, M., Reay, D.S., 455 Curtis, C., Siemens, J., Maberly, S., Kaste, Ø., Humborg, C., Loeb, R., de Klein, J., Hejzlar, J., Skoulikidis, N., Kortelainen, P., Lepistö, A., and Wright, R.: 7 - Nitrogen processes in aquatic ecosystems, in: The European Nitrogen Assessment: Sources, Effects and Policy Perspectives, edited by: Bleeker, A., Grizzetti, B., Howard, C.M., Billen, G., van Grinsven, H., Erisman, J.W., Sutton, M.A., and Grennfelt, P., Cambridge University Press, Cambridge, UK, 126-146, https://doi.org/10.1017/CBO9780511976988.010, 2011.

460 Glasaite, R. and Šatkauskienè, I.: Periphyton composition and diversity in the Kaunas Lagoon and the Nemunas River, Biologija, 59(2), 141-150, https://doi.org/10.6001/biologija.v59i2.2746, 2013.

Hall Jr, R.O., Tank, J.L., Sobota, D.J., Mulholland, P.J., O'Brien, J.M., Dodds, W.K., Webster, J.R., Valett, H.M., Poole, G.C., Peterson, B.J., Meyer, J.L., McDowell, W.H., Johnson, S.L., Hamilton, S.K., Grimm, N.B., Gregory, S.V., Dahm, C.N., Cooper, L.W., Ashkenas, L.R., Thomas, S.M., Sheibley, R.W., Potter, J.D., Niederlehner, B.R., Johnson, L.T., Helton, A.M., 465 Crenshaw, C.M., Burgin, A.J., Bernot, M.J., Beaulieu, J.J., and Arangob, C.P.: Nitrate removal in stream ecosystems measured by $15 \mathrm{~N}$ addition experiments: Total uptake, Limnol. Oceanogr., 54(3), 653-665, https://doi.org/10.4319/lo.2009.54.3.0653, 2009. 
Hamilton, D.P., Carey, C.C., Arvola, L., Arzberger, P., Brewer, C., Cole, J.J., Gaiser, E., Hanson, P.C., Ibelings, B.W., Jennings, E., Kratz, T.K., Lin, F.-P., McBride, C.G., David de Marques, M., Muraoka, K., Nishri, A., Qin, B., Read, J.S., Rose, K.C., Ryder, E., Weathers, K.C., Zhu, G., Trolle, D., and Brookes, J.D.: A Global Lake Ecological Observatory Network (GLEON) for synthesising high-frequency sensor data for validation of deterministic ecological models, Inland Waters, 5(1), 49-56, https://doi.org/10.5268/IW-5.1.566, 2015.

Hardenbicker, P., Rolinski, S., Weitere, M., and Fischer, H.: Contrasting long-term trends and shifts in phytoplankton dynamics in two large rivers, Int. Rev. Hydrobiol., 99(4), 287-299, https://doi.org/10.1002/iroh.201301680, 2014.

Heffernan, J.B. and Cohen, M.J.: Direct and indirect coupling of primary production and diel nitrate dynamics in a subtropical spring-fed river, Limnol. Oceanogr., 55(2), 677-688, https://doi.org/10.4319/lo.2010.55.2.0677, 2010.

Hensley, R.T. and Cohen, M.J.: Nitrate depletion dynamics and primary production in riverine benthic chambers, Freshw. Sci., 39(1), 169-182, https://doi.org/10.1086/707650, 2020.

Hensley, R.T., Cohen, M.J., and Korhnak, L.V.: Inferring nitrogen removal in large rivers from high-resolution longitudinal profiling, Limnol. Oceanogr., 59(4), 1152-1170, https://doi.org/10.4319/lo.2014.59.4.1152, 2014.

Hensley, R.T., Kirk, L., Spangler, M., Gooseff, M.N., and Cohen, M.J.: Flow extremes as spatiotemporal control points on river solute fluxes and metabolism, J. Geophys. Res. Biogeosci., 124(3), 537-555, https://doi.org/10.1029/2018JG004738, 2019.

Huang, J., Yin, H., Jomaa, S., Rode, M., and Zhou, Q.: Limited nitrogen retention in an urban river receiving raw sewage and wastewater treatment plant effluent, Environ. Sci.: Process. Impacts., 21, 1477-1488, https://doi.org/10.1039/C9EM00201D, 2019.

Jäger, C.G. and Borchardt, D.: Longitudinal patterns and response lengths of algae in riverine ecosystems: A model analysis emphasising benthic-pelagic interactions, J. Theor. Biol., 442, 66-78, https://doi.org/10.1016/j.jtbi.2018.01.009, 2018.

Kamjunke, N., Mages, M., Büttner, O., Marcus, H., and Weitere, M.: Relationship between the elemental composition of stream biofilms and water chemistry - a catchment approach, Environ. Monit. Assess., 187(7), 432, https://doi.org/10.1007/s10661-015-4664-6, 2015.

Kamjunke, N., Rode, M., Baborowski, M., Kunz, J.V., Zehner, J., Borchardt, D., and Weitere, M.: High irradiation and low discharge promote the dominant role of phytoplankton in riverine nutrient dynamics, Limnol. Oceanogr., 66(7), 2648-2660, https://doi.org/10.1002/lno.11778, 2021.

495 Khorashadi Zadeh, F., Nossent, J., Woldegiorgis, B.T., Bauwens, W., and van Griensven, A.: Impact of measurement error and limited data frequency on parameter estimation and uncertainty quantification, Environ. Model. Softw., 118, 35-47, https://doi.org/10.1016/j.envsoft.2019.03.022, 2019.

Kong, X., Zhan, Q., Boehrer, B., and Rinke, K.: High frequency data provide new insights into evaluating and modeling nitrogen retention in reservoirs, Water Res., 166, 115017, https://doi.org/10.1016/j.watres.2019.115017, 2019. 
Kunz, J.V., Hensley, R., Brase, L., Borchardt, D., and Rode, M.: High frequency measurements of reach scale nitrogen uptake in a fourth order river with contrasting hydromorphology and variable water chemistry (Weiße Elster, Germany), Water Resour. Res., 53(1), 328-343, https://doi.org/10.1002/2016WR019355, 2017.

Lepoint, G., Gobert, S., Dauby, P., and Bouquegneau, J.-M.: Contributions of benthic and planktonic primary producers to nitrate and ammonium uptake fluxes in a nutrient-poor shallow coastal area (Corsica, NW Mediterranean), J. Exp. Mar. Biol. Ecol., 302(1), 107-122, https://doi.org/10.1016/j.jembe.2003.10.005, 2004.

Landesbetrieb für Hochwasserschutz und Wasserwirtschaft Sachsen-Anhalt (LHW): Niedrigwasserbewirtschaftungsmodell Untere Bode Endbericht, Magdeburg, Germany, 2012.

Martin, J.L., Robert B., and Wool, T.A.: WASP7 Benthic Algae - Model Theory and User's Guide, Supplement to Water Analysis Simulation Program (WASP) User Documentation, US Environmental Protection Agency - Region 4, Atlanta, GA, 510 US, 2017.

Matott, L.: OSTRICH: an Optimization Software Tool, Documentation and User's Guide, Version 17.12.19, University at Buffalo Center for Computational Research, US, 2017.

Mulholland, P.J., Helton, A.M., Poole, G.C., Hall, R.O., Hamilton, S.K., Peterson, B.J., Tank, J.L., Ashkenas, L.R., Cooper, L.W., Dahm, C.N., Dodds, W.K., Findlay, S.E.G., Gregory, S.V., Grimm, N.B., Johnson, S.L., McDowell, W.H., Meyer, J.L., 515 Valett, H.M., Webster, J.R., Arango, C.P., Beaulieu, J.J., Bernot, M.J., Burgin, A.J., Crenshaw, C.L., Johnson, L.T., Niederlehner, B.R., O'Brien, J.M., Potter, J.D., Sheibley, R.W., Sobota, D.J., and Thomas, S.M.: Stream denitrification across biomes and its response to anthropogenic nitrate loading, Nature, 452, 202-205, https://doi.org/10.1038/nature06686, 2008.

Pianosi, F., Sarrazin, F., and Wagener, T.: A Matlab toolbox for Global Sensitivity Analysis, Environ. Model. Softw. 70, 8085, https://doi.org/10.1016/j.envsoft.2015.04.009, 2015.

520 Raimonet, M., Vilmin, L., Flipo, N., Rocher, V., and Laverman, A.M.: Modelling the fate of nitrite in an urbanized river using experimentally obtained nitrifier growth parameters, Water Res., 73, 373-387, https://doi.org/10.1016/j.watres.2015.01.026, 2015.

Reynolds, C.S. and Descy, J.P.: The production, biomass and structure of phytoplankton in large rivers, Large Rivers, 10, 161187, https://doi.org/10.1127//r/10/1996/161, 1996.

525 Riis, T., Dodds, W.K., Kristensen, P.B., and Baisner, A.J.: Nitrogen cycling and dynamics in a macrophyte-rich stream as determined by a release, Freshw. Biol., 57(8), 1579-1591, https://doi.org/10.1111/j.1365-2427.2012.02819.x, 2012.

Rimet, F., Bouchez, A., and Montuelle, B.: Benthic diatoms and phytoplankton to assess nutrients in a large lake: Complementarity of their use in Lake Geneva (France-Switzerland), Ecol. Indic., 53, 231-239, https://doi.org/10.1016/j.ecolind.2015.02.008, 2015.

530 Redfield, A.C.: The biological control of chemical factors in the environment, Am. Sci. 46(3), 230A, 205-221. 1958.

Rode, M., Halbedel née Angelstein, S., Anis, M.R., Borchardt, D., and Weitere, M.: Continuous in-stream assimilatory nitrate uptake from high-frequency sensor measurements, Environ. Sci. Technol., 50(11), 5685-5694, https://doi.org/10.1021/acs.est.6b00943, 2016a. 
Rode, M., Wade, A.J., Cohen, M.J., Hensley, R.T., Bowes, M.J., Kirchner, J.W., Arhonditsis, G.B., Jordan, P., Kronvang, B., Halliday, S.J., Skeffington, R.A., Rozemeijer, J.C., Aubert, A.H., Rinke, K., and Jomaa, S.: Sensors in the stream: the highfrequency wave of the present, Environ. Sci. Technol., 50(19), 10297-10307, https://doi.org/10.1021/acs.est.6b02155, 2016b Rutherford, J.C., Young, R.G., Quinn, J.M., Chapra, S.C., and Wilcock, R.J.: Nutrient attenuation in streams: a simplified model to explain field observations, J. Environ. Eng., 146(8): 04020092, https://doi.org/10.1061/(ASCE)EE.1943$7870.0001753,2020$.

540 Sommer, U., Adrian, R., De Senerpont Domis, L., Elser, J.J., Gaedke, U., Ibelings, B., Jeppesen, E., Lürling, M., Molinero, J.C., Mooij, W.M., van Donk, E., and Winder, M.: Beyond the Plankton Ecology Group (PEG) Model: Mechanisms Driving Plankton Succession, Annu. Rev. Ecol. Evol., 43(1), 429-448, https://doi.org/10.1146/annurev-ecolsys-110411-160251, 2012. Tank, J.L., Martí, E., Riis, T., von Schiller, D., Reisinger, A.J., Dodds, W.K., Whiles, M.R., Ashkenas, L.R., Bowden, W.B., Collins, S.M., Crenshaw, C.L., Crowl, T.A., Griffiths, N.A., Grimm, N.B., Hamilton, S.K., Johnson, S.L., McDowell, W.H., 545 Norman, B.M., Rosi, E.J., Simon, K.S., Thomas, S.A., and Webster, J.R.: Partitioning assimilatory nitrogen uptake in streams: an analysis of stable isotope tracer additions across continents, Ecol. Monogr., 88(1), 120-138, https://doi.org/10.1002/ecm.1280, 2018.

Tank, J.L., Reisinger, A.J., and Rosi, E.J.: Chapter 31 - Nutrient limitation and uptake, in: Methods in Stream Ecology (Third Edition), edited by: Lamberti, G.A. and and Hauer, F.R., Academic Press, Elsevier, 147-171, https://doi.org/10.1016/B978-012-813047-6.00009-7, 2017.

Vannote, R.L., Minshall, G.W., Cummins, K.W., Sedell, J.R., and Cushing, C.E.: The River Continuum Concept, Can. J. Fish. Aquat. Sci., 37(1), 130-137, https://doi.org/10.1139/f80-017, 1980.

Verstraete, W. and Focht, D.D.: Biochemical ecology of nitrification and denitrification, in: Advances in Microbial Ecology, edited by: Alexander, M., Springer, Boston, MA, US, 135-214, https://doi.org/10.1007/978-1-4615-8219-9_4, 1977.

von Schiller, D., Bernal, S., Sabater, F., and Martí, E.: A round-trip ticket: the importance of release processes for in-stream nutrient spiraling, Freshw. Sci., 34(1), 20-30, https://doi.org/10.1086/679015, 2015.

Wagenschein, D. and Rode, M.: Modelling the impact of river morphology on nitrogen retention-A case study of the Weisse Elster River (Germany), Ecol. Modell., 211(1-2), 224-232, https://doi.org/10.1016/j.ecolmodel.2007.09.009, 2008.

Wool, T., Ambrose, R.B., Martin, J.L., and Comer, E.A.: WASP 8: The Next Generation in the 50-year Evolution of USEPA's 560 Water Quality Model, Water, 12(5), https://doi.org/10.3390/w12051398, 2020.

Wool, T.A., Ambrose, R.B., Martin, J.L., and Comer, E.A.: Water Quality Analysis Simulation Program (WASP) Version 6.0 DRAFT: User's Manual, US Environmental Protection Agency - Region 4, Atlanta, GA, US, 2002.

Yang, S., Bertuzzo, E., Büttner, O., Borchardt, D., and Rao, P.S.C.: Emergent spatial patterns of competing benthic and pelagic algae in a river network: A parsimonious basin-scale modeling analysis, Water Res., 193, 116887, 565 https://doi.org/10.1016/j.watres.2021.116887, 2021. 